\title{
Mechanisms Underlying Endothelin-1 Level Elevations Caused by Excessive Fluoride Exposure
}

\author{
Liyan Sun Yanhui Gao Wei Zhang Xiaona Liu Bingyun Li Xiaohui Cui \\ Dianjun Sun
}

Center for Endemic Disease Control, Chinese Center for Disease Control and Prevention, Harbin Medical University; Key Lab of Etiology and Epidemiology, Education Bureau of Heilongjiang Province \& Ministry of Health (23618504), Harbin, China

\section{Key Words}

Endothelin-1 - Endothelin-converting enzyme-1 - Extracellular signal-regulating kinase 1/2 • Fluorosis • Reactive oxygen species

\begin{abstract}
Objective: To explore the mechanisms underlying endothelin-1 (ET-1) elevations induced by excessive fluoride exposure. Methods: We measured serum and bone fluoride ion content and plasma ET-1 levels and compared these parameters among different groups in an animal model. We also observed morphological changes in the aorta and endothelium of rabbits. In cell experiments, human umbilical vein endothelial cells (HUVECs) were treated with varying concentrations of $\mathrm{NaF}$ for $24 \mathrm{~h}$, with or without $10 \mu \mathrm{M}$ U0126 pretreatment for $1 \mathrm{~h}$. ET-1 levels in culture fluid and intracellular reactive oxygen species (ROS) levels, as well as ET1 gene, endothelin-converting enzyme-1 (ECE-1), extracellular signal-regulating kinase $1 / 2$ (ERK1/2), pERK1/2 expression levels and RAS activation were measured and compared among the groups. Results: Plasma ET-1 levels of rabbits increased significantly in fluorinated groups compared with those in the control group. The rabbit thoracic aortas became slightly hardened in fluorinated groups compared with those in the control group, and some vacuoles were present in the endothelial cell cytoplasm of the rabbits in fluorinated groups. In our cell experiments, ET1 gene and ECE-1 expression levels in HUVECs and ET-1 expression levels in the cell culture supernatants increased significantly in some experimental groups compared with those in the control group. These trends paralleled the changes in intracellular ROS levels, RAS activation, and the pERK1/2-to-ERK1/2 ratio. After U0126 was added, ECE-1 expression and ET-1 levels decreased significantly. Conclusion: Excessive fluoride exposure leads to characteristic endothelial damage (vacuoles), thoracic aorta hardening, and plasma ET-1 level elevations in rabbits. In addition, the ROS-RAS-MEK1/2-pERK1/2/ERK1/2 pathway plays a crucial-and at least partial-role in ET-1 over-expression, which is promoted by excessive fluoride exposure.

L. Sun and Y. Gao contributed equally to this work. 


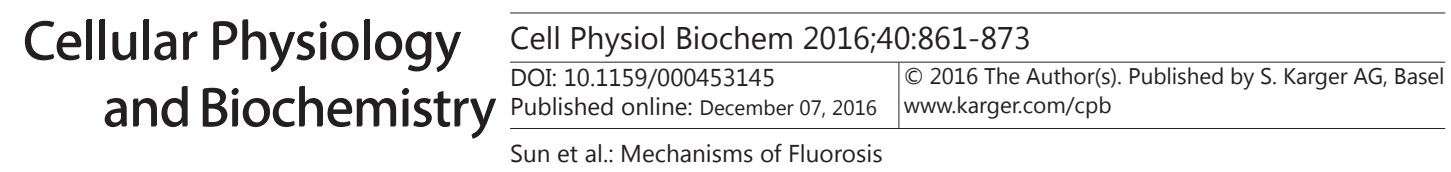

\section{Introduction}

Endemic fluorosis is a worldwide disease that seriously harms the health of residents in some endemic areas of China, India, and Africa. The disease manifests as dental and skeletal fluorosis, which affect young children and adults, respectively. In addition to causing skeletal and dental damage, excessive exposure to fluoride can exert other pathophysiologic effects. Specifically, excessive exposure to fluoride can cause metabolic, structural, and functional damage to the nervous system [1], kidneys, liver [2, 3], and cardiovascular system [4-6] and can reduce the intellectual capacity of children $[7,8]$. In the past, the non-bone-related damage caused by fluorosis has often been overlooked because the onset of symptoms resulting from this damage is slow, and the injuries inflicted by this damage are nonspecific.

In recent years, public concern regarding the damage to the cardiovascular system caused by excessive fluoride exposure has increased, particularly concern regarding the atherosclerosis and hypertension caused by excessive fluoride exposure. Our team found that excessive fluoride intake from drinking water is not only closely associated with essential hypertension [5] but also is associated with atherosclerosis [6]. We also found that high fluoride exposure increases plasma endothelin-1 (ET-1) levels in subjects living in endemic fluoride areas [5].

As the most potent vasoconstrictive agent [9], ET-1 enhances vasoconstriction and exacerbates the processes of hypertension and atherosclerosis by aggravating cell hyperplasia and vascular smooth muscle cell migration [10-14]. ET-1 was originally isolated from porcine aortic endothelial cells and is predominantly secreted by endothelial cells. Mature ET-1 production is mainly controlled by endothelin-converting enzyme 1 (ECE-1) [15]. The results of ECE gene knockout studies suggest that ECE-1 is the major functional ECE in vivo, although additional ECE isoforms have been identified in animals and humans [16]. Therefore, ECE-1 is the limiting enzyme in ET-1 synthesis [17].

Some factors known to promote ET-1 production include insulin, angiotensin II, inflammatory mediators, oxidative stress and vascular shear stress [18]. Similarly, a signaling pathway also appears to be involved in ET-1 synthesis. Previous studies have reported that the extracellular signal-regulating kinase $1 / 2($ ERK1/2) signaling pathway plays a key role in ET-1 synthesis and secretion. ERK1/2 phosphorylation activates multiple transcription factors to not only enhance ET-1 production but also promote smooth muscle contraction, which is mediated by ET-1 $[19,20]$.

We inferred from our previous results that ET-1 plays a vital role in the development of hypertension and atherosclerosis caused by excessive fluoride exposure. However, the specific mechanism by which excessive fluoride exposure increases plasma ET-1 levels remains unclear. Therefore, the aim of this study was to explore the exact mechanism by which excessive fluoride exposure enhances plasma ET-1 levels.

\section{Materials and Methods}

\section{Animals and treatment}

Twenty-four healthy, clean and male Japanese big-eared rabbits (2400-2600g) were selected and housed in an air-conditioned room with $45 \%-65 \%$ humidity and a temperature of $20 \pm 2{ }^{\circ} \mathrm{C}$. After a week of adaptive feeding, the rabbits were randomly assigned to three groups of eight animals each, according to their initial weights. Based on an earlier results of our team, the highly fluoridated water contained $100 \mathrm{mg}$ fluoride ion/L, and the slightly fluoridated water contained $50 \mathrm{mg}$ fluoride ion/L. Different groups of rabbits were given basic feed and drank tap water or fluoridated water (50 or $100 \mathrm{mg}$ fluoride ion/L; the water was fluoridated with sodium fluoride). The experimental design of the study is presented in Table 1 . The feed and assigned drinking water were available at all times throughout the experiment. The rabbits were exposed to fluoride for 5 months and then sacrificed under chloral hydrate anesthesia. All the experiments were approved by the Animal Ethics Committee of Harbin Medical University. 


\section{Cellular Physiology Cell Physiol Biochem 2016;40:861-873 \begin{tabular}{ll|l} 
DOI: 10.1159/000453145 & $\begin{array}{l}\text { O 2016 The Author(s). Published by S. Karger AG, Basel } \\
\text { www.karger.com/cpb }\end{array}$ \\
\cline { 1 - 3 } & Published online: December 07, 2016
\end{tabular} \\ Sun et al.: Mechanisms of Fluorosis}

Table 1. Diet and drinking water in the different groups. ${ }^{1}$ Group A is the control group. ${ }^{2}$ The basic feed formula included soybean meal (10\%), milled barley (38\%), bran (50\%), salt (1\%) and fish meal $(1 \%) .{ }^{3}$ The concentration of fluorion in the tap water was $0.38 \mathrm{mg} / \mathrm{L}$

\begin{tabular}{lll}
\hline Group & Diet & Drinking water \\
\hline A $^{1}$ & Basic feed $^{2}$ & Tap water $^{3}$ \\
B & Basic feed & Slightly fluoridated water \\
C & Basic feed & Highly fluoridated water \\
\hline
\end{tabular}

\section{Detection of fluoride ions in rabbit serum}

Blood samples (not less than $2 \mathrm{~mL} / \mathrm{rabbit}$ ) were drawn from the femoral artery, collected in 5-mL tubes and then allowed to stand at room temperature for $1 \mathrm{~h}$. The samples were centrifuged at $3000 \mathrm{~g}$ for $10 \mathrm{~min}$ at $4{ }^{\circ} \mathrm{C}$ to separate the sera, which were dispensed into microcentrifuge tubes as 120 - $\mu \mathrm{L}$ aliquots and stored at $-80{ }^{\circ} \mathrm{C}$ until analysis. All analytical measurements of fluoride ion levels in serum were performed according to the standard methods used in China. All samples were measured three times (independent aliquots), and the mean of the three determinations was used as the serum fluoride ion concentration.

\section{Detection of fluoride ions in the bones of rabbits}

Tibia samples were removed from the rabbits, after which the attached soft tissues were thoroughly removed, and the bones were split open and cleaned of marrow with cold phosphate-buffered saline (PBS). The treated samples were subsequently dried at $105^{\circ} \mathrm{C}$ for $4 \mathrm{~h}$ and ashed at $550^{\circ} \mathrm{C}$ for $6 \mathrm{~h}$. The bone ash (25g) was dissolved in $1 \mathrm{~N}$ HCL $(5 \mathrm{~mL})$ and neutralized with $1 \mathrm{~N} \mathrm{NAOH}$, and then $12.5 \mathrm{~mL}$ of TISAB was added to the mixture. Fluoride ion concentrations were measured with a fluoride ion-selective electrode (Yingke Crystal Materials Company, Changsha, China). All bone samples were measured three times (independent aliquots), and the mean of the three determinations was used as the bone fluoride ion concentration.

\section{Morphological observation of rabbit aortas and endothelial cells}

The upper and middle sections of the thoracic aorta of each rabbit were removed and opened longitudinally. The inner wall of the blood vessel was observed with the naked eye, and photographs were taken with a digital camera. The lower section of the thoracic aorta was removed and fixed in 2.5\% glutaraldehyde solution and was then sent to the Center for Electron Microscopy of Harbin Medical University, where changes in the endothelial cells were examined via transmission electron microscopy.

\section{Assay of plasma ET-1 levels in rabbits}

Blood samples (not less than $2 \mathrm{~mL} / \mathrm{rabbit}$ ) were drawn from the femoral artery, collected in 5-mL anticoagulant tubes containing $10 \%$ ethylene diamine tetraacetic acid and then allowed to stand at room temperature for $1 \mathrm{~h}$. The samples were centrifuged at $3000 \mathrm{~g}$ for $10 \mathrm{~min}$ at $4{ }^{\circ} \mathrm{C}$ to separate the plasma, and $120-\mu \mathrm{L}$ aliquots of the separated plasma were dispensed into microcentrifuge tubes and stored at $-80{ }^{\circ} \mathrm{C}$ until analysis. ET-1 levels in the plasma were measured with an Endothelin Radioimmunoassay Kit (Beijing North Institute of Biological Technology, D11PJB, Beijing, China), according to the protocol supplied with the kit.

\section{Cell culture and treatment}

Human umbilical vein endothelial cells (HUVECs) were purchased from the Shanghai Cell Bank of the Chinese Academy of Sciences, Shanghai, China. The HUVECs were maintained in growth medium containing Dulbecco's modified Eagle medium with high glucose supplemented with $10 \%$ fetal calf serum, penicillin (100 units $/ \mathrm{mL}$ ) and streptomycin $(100 \mu \mathrm{g} / \mathrm{mL})$. The growth medium was changed every 2 days. In this experiment, the HUVECs were treated with varying concentrations of $\mathrm{NaF}(0,0.4,0.8$, or $1.2 \mu \mathrm{g} / \mathrm{mL})$ for $24 \mathrm{~h}$, with or without pretreatment with $10 \mu \mathrm{M}$ U0126 (amitogen-activated protein kinase (MAPK)/ERK (MEK) $1 / 2$ inhibitor) for $1 \mathrm{~h}$.

\section{Cell proliferation assay}

HUVECs proliferation was assessed via Cell Counting Kit-8 assay (Beyotime Institute of Biotechnology, Shanghai, China). The cells were treated with different concentrations of fluoride ion $(0.06,0.12,0.18,0.24$, $0.3,0.6,0.9,1.2,1.5,1.8,2.1$, or $2.4 \mu \mathrm{g} / \mathrm{mL})$ for $24 \mathrm{~h}$. CCK-8 solution $(20 \mu \mathrm{L})$ was then added to each well of the plate, and the cells were incubated for $2 \mathrm{~h}$ at $37^{\circ} \mathrm{C}$ under $5 \% \mathrm{CO}_{2}$. The optical density (OD) was measured at a 


\section{Cellular Physiology Cell Physiol Biochem 2016;40:861-873 and Biochemistry Published online: December 07, $2016 \quad \begin{aligned} & \text { DOI: 10.1159/000453145 } 2016 \text { The Author(s). Published by S. Karger AG, Basel } \\ & \text { www.karger.com/cpb }\end{aligned}$ \\ Sun et al:: Mechanisms of Fluorosis}

wave length of $450 \mathrm{~nm}\left(\mathrm{OD}_{450}\right)$ on a Cytation 3 Cell Imaging Reader (BioTek Instruments Inc, Highland Park, Vermont, USA). The $\mathrm{OD}_{450}$ value was correlated positively with cell proliferation, so it was used to directly represent cell proliferation and survival in this experiment.

Quantitative real-time PCR

Total RNA was extracted from HUVECs using an RNAiso Plus Total RNA Extraction Kit. Reverse transcription $\left(37^{\circ} \mathrm{C}\right.$ for $15 \mathrm{~min}$ and $85^{\circ} \mathrm{C}$ for $5 \mathrm{~s}$ ) and quantitative PCR (qPCR) were performed with a Prime Script RT Reagent Kit and SYBR Premix Ex Taq, respectively. These three kits were purchased from TaKaRa Biotechnology Co., Ltd, Dalian, China. The experiments were performed according to the manufacturer's instructions. The primers were designed according to the appropriate gene sequences in GenBank. The PCR cycling conditions consisted of an initial denaturation step of $95^{\circ} \mathrm{C}$ for 30 s, followed by 40 cycles of $95{ }^{\circ} \mathrm{C}$ for $5 \mathrm{~s}, 56^{\circ} \mathrm{C}$ for $15 \mathrm{~s}$, and $72{ }^{\circ} \mathrm{C}$ for $15 \mathrm{~s}$, as well as a final extension at $72{ }^{\circ} \mathrm{C}$ for $60 \mathrm{~s}$. The experiments were performed on a Chromo4 Real-Time PCR Detector (Bio-Rad Laboratories, Hercules, California, USA). The results were calculated with the $\Delta \mathrm{Ct}$ method and normalized to $\beta$-actin expression in each sample.

Assay of ET-1 levels in cell culture supernatants

Endothelial cell culture fluid from the different dose groups (treated for $24 \mathrm{~h}$ ) was collected and centrifuged at $3000 \mathrm{~g}$ for $10 \mathrm{~min}$ at $4{ }^{\circ} \mathrm{C}$ to separate the supernatants, which were then dispensed into microcentrifuge tubes as $120-\mu \mathrm{L}$ aliquots and stored at $-80^{\circ} \mathrm{C}$ until analysis. The total protein concentrations were quantified with a bicinchoninic acid (BCA) protein assay kit (Beyotime Institute of Biotechnology, Shanghai, China), and ET-1 levels in the cell culture supernatants were measured with an ET-1 enzyme-linked immunosorbent assay (ELISA) kit (Immuno-Biological Laboratories Co., Ltd, Gunma, Japan), according to the protocol provided with the kit.

\section{Automated western blotting with Simon ${ }^{\text {TM }}$}

The treated cells were washed twice with ice-cold PBS and then incubated in lysis buffer containing RIPA (Beyotime Institute of Biotechnology, Shanghai, China), a protease inhibitor and phosphatase inhibitors (Roche Pharmaceutical Ltd, Basel, Switzerland) on ice for $30 \mathrm{~min}$. The cells were then centrifuged at 14,000 $\mathrm{g}$ for $10 \mathrm{~min}$ at $4^{\circ} \mathrm{C}$. The samples were kept cold and used immediately or frozen and stored at $-80{ }^{\circ} \mathrm{C}$ until analysis. The total protein concentration was measured with a BCA assay kit (Beyotime Institute of Biotechnology, Shanghai, China). The levels of ECE-1, ERK1/2, phosphorylated ERK1/2 (pERK1/2), and GAPDH protein were quantified with an automated Simon Simple Western ${ }^{\text {TM }}$ System (ProteinSimple; Santa Clara, California, USA). This technique is automated and eliminates the blotting step, which allows more accurate and reproducible protein level measurements. Anti-pERK and anti-ERK antibodies were purchased from Cell Signaling Technology, Inc. (Danvers, Massachusetts, USA), anti-ECE-1 antibodies were purchased from Santa Cruz Biotechnology, Inc. (Santa Cruz, California, USA), and anti-GAPDH antibodies were purchased from Zhongshan Golden Bridge Biotechnology (Beijing, China). All the primary antibodies were diluted 1:100. The proteins were quantified and analyzed with Compass software (ProteinSimple, San Jose, California, USA).

\section{RAS activation assay}

The treated cells (treated with different concentrations of fluoride ion for $24 \mathrm{~h}$ ) were washed twice with ice-cold Tris-buffered saline, and the supernatant was discarded. $\mathrm{Mg}^{2+}$ lysis/wash buffer prepared from the $5 \times \mathrm{Mg}^{2+}$ lysis/wash buffer included in the Ras Activation ELISA Assay Kit (Millipore Corporation, Billerica, Massachusetts, USA) was added to the mixture, and the cells were scraped from the plate. The cells were then transferred to microcentrifuge tubes in lysis buffer, incubated on ice for $15 \mathrm{~min}$, and centrifuged at $14,000 \mathrm{~g}$ for $10 \mathrm{~min}$ at $4{ }^{\circ} \mathrm{C}$. The samples were kept cold and used immediately or frozen and stored at $-80^{\circ} \mathrm{C}$ until analysis. The total protein concentrations were then measured with a BCA assay kit. The assays were performed, and the results were calculated according to the manuals provided with the kits.

Measurement of intracellular reactive oxygen species (ROS) levels

HUVECs were treated with different concentrations of fluoride ion for $24 \mathrm{~h}$. The cells were then collected and resuspended in dilute $2^{\prime} 7^{\prime}$-dichlorofluorescein diacetate solution at a density $1-20 \times 10^{6}$ cells $/ \mathrm{mL}$. The mixture was incubated at $37^{\circ} \mathrm{C}$ for $20 \mathrm{~min}$ and then washed three times with serum-free culture medium. 


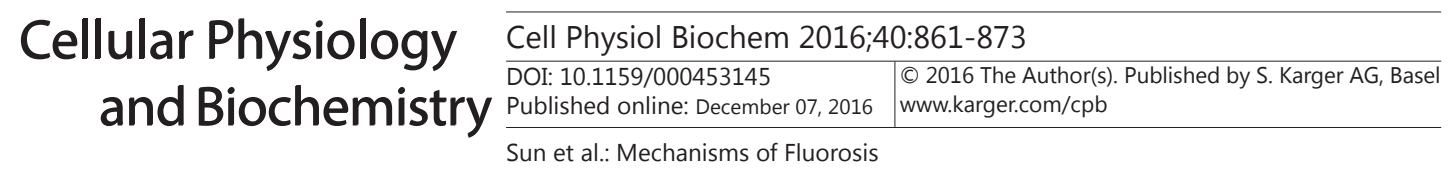

The cells were subsequently suspended in $0.5 \mathrm{~mL}$ of serum-free culture medium, and their fluorescence intensity was measured with a flow cytometer (Becton, Dickinson and Company, New York, USA).

\section{Statistical analysis}

All data were recorded with EpiData 3.02 and analyzed with SPSS 17.0 software (International Business Machines Corporation, Armonk, New York, USA). The results are presented as means \pm SEM. Comparisons of ECE-1 expression and ET-1 $(1.2 \mu \mathrm{g} / \mathrm{mL})$ levels with and without U0126 pretreatment were made with Student's $t$ test. All other indices were compared among all the experimental groups with one-way ANOVA. Dunnett's T3 and the least significant difference tests were used for all two-group comparisons. All tests were two-tailed, and $\mathrm{P}<0.05$ was considered statistically significant.

\section{Results}

No significant differences in bodyweight with time were observed among three groups throughout experiment

During the first month, the bodyweights of experimental animals increased steadily in all three groups. However, after the second month, the changes in the body weights of experimental animals varied among different groups. The details are shown in Figure 1A. There was no significant difference in bodyweight among three groups throughout experiment. Some rabbits died after the second month. At the end of experiment, groups A, $\mathrm{B}$, and $\mathrm{C}$ comprised 6,7 , and 6 rabbits, respectively.

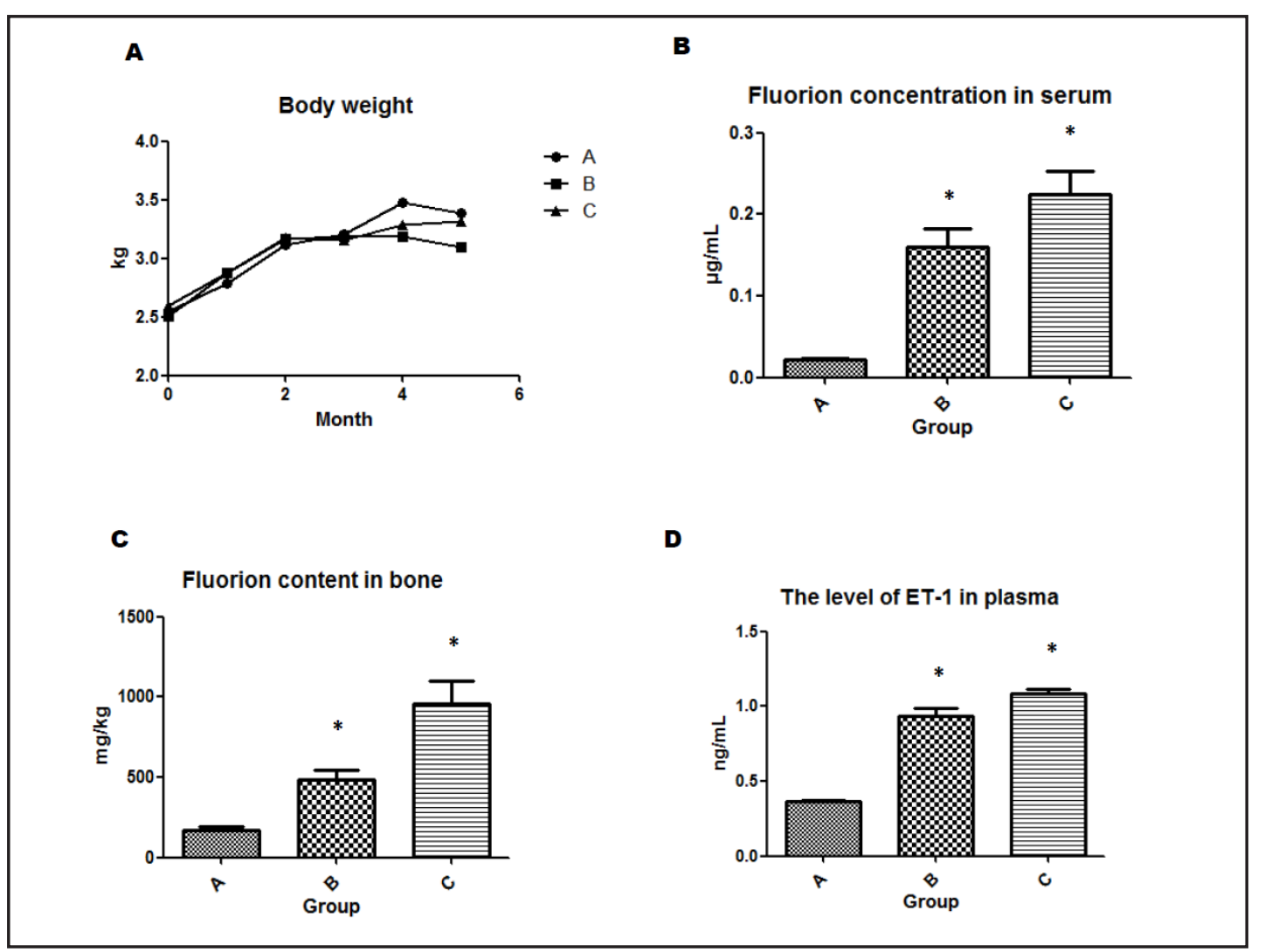

Fig. 1. Changes in body weight and fluoride ion concentrations and content in serum and bones and the levels of ET-1 in plasma of rabbits in three groups. Part A shows the changes in body weights of rabbits in all three groups with time. Part B shows fluoride ion concentrations in serum. Part $\mathrm{C}$ shows the fluoride ion content in bone. Part D shows the levels of ET- 1 in plasma of rabbits in three groups. ${ }^{*} \mathrm{P}<0.01$ compared with Group A. 


\section{Cellular Physiology and Biochemistry

Fig. 2. Morphological changes in aortas and endothelia of the experimental animals in different groups. Parts A, B, and C show gross changes in the inner wall of aortas in groups A, $B$, and $C$, respectively. Parts $D$, $\mathrm{E}$, and $\mathrm{F}$ show the morphological changes in aortic endothelia in groups $\mathrm{A}, \mathrm{B}$, and $\mathrm{C}$, respectively. The red arrows indicate the distinctive vacuoles in endothelial cell cytoplasm. The magnification of parts $\mathrm{D}, \mathrm{E}$, and $\mathrm{F}$ is $\times 12,000$.

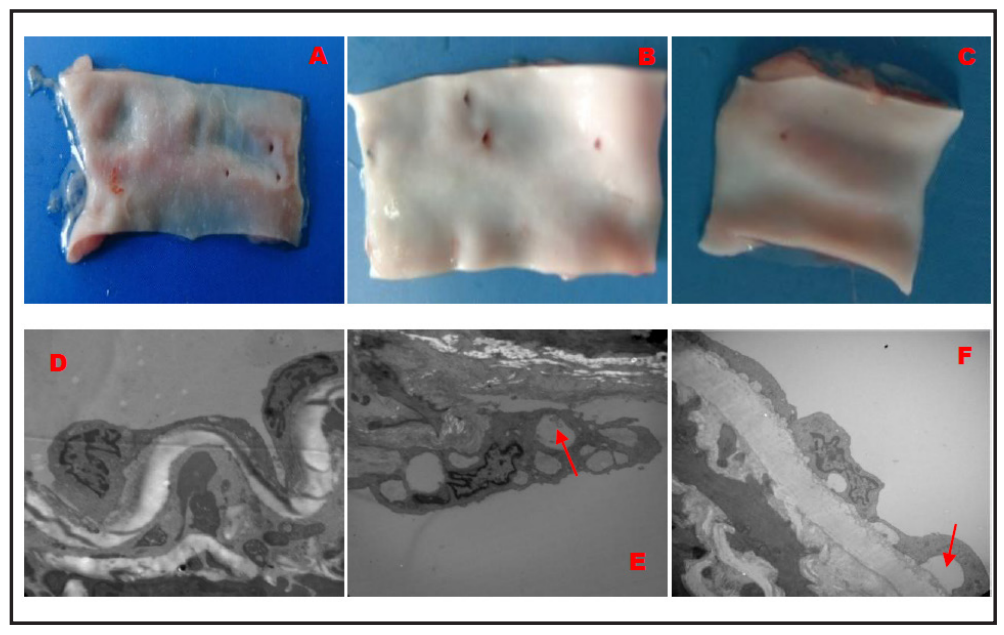

The animal model of excessive fluoride exposure was successfully established by administering NaF to rabbits via their drinking water

The fluoride ion concentrations in sera of rabbits in groups $\mathrm{B}$ and $\mathrm{C}$ were significantly higher than those of rabbits in group $\mathrm{A}(\mathrm{F}=22.89, \mathrm{P}<0.001$; Fig. $1 \mathrm{~B})$, but there were no significant differences in fluoride ion concentrations between groups $\mathrm{B}$ and $\mathrm{C}$, indicating that excessive intake of fluoride via drinking water markedly affects serum fluoride ion concentrations.

The fluoride ion content in bones of rabbits in groups B and C was significantly higher than that in bones of rabbits in group $\mathrm{A}(\mathrm{F}=18.94, \mathrm{P}<0.001$; Fig. $1 \mathrm{C})$, but groups $\mathrm{B}$ and $\mathrm{C}$ did not differ significantly with respect to bone fluoride ion content. Taken together, these results indicate that the animal model of excessive fluoride exposure was successfully established by administering $\mathrm{NaF}$ to rabbits via their drinking water.

ET-1 levels in plasma of rabbits in two fluorinated groups were significantly elevated

In the animal experiment, the levels of ET- 1 in plasma of groups A, B, and C were 0.36 $\pm 0.03,0.94 \pm 0.14$, and $1.09 \pm 0.08 \mathrm{ng} / \mathrm{mL}$, respectively, and differed significantly among the three groups ( $\mathrm{F}=90.96, \mathrm{P}<0.001$; Fig. 1D). Pair-wise comparisons were performed and revealed that the levels of ET-1 in plasma of groups B and C were significantly higher than those in the control group $(\mathrm{P}<0.001)$. Furthermore, the levels of ET- 1 in plasma of group $\mathrm{C}$ were significantly higher than those in group $B(P=0.015)$.

The aortas of rabbits in two fluorinated groups exhibited slight hardening, and many distinctive vacuoles were apparent in cytoplasm of endothelial cells in these groups

The aortas of rabbits in the control group were soft and elastic, and their inner walls were smooth and glossy (Fig. 2A), while the aortas of rabbits in groups B and C exhibited diminished elasticity, with slight hardening, as well as darker and slight gray-while gloss on their inner walls (Fig. 2B and 2C).

Transmission electron microscopy demonstrated that the structure of endothelium in Group A was normal and the cell nuclei were clearly visible. The endothelial cell layer and basement membrane were continuous, and the elastic layer was unbroken (Fig. 2D). In groups $\mathrm{B}$ and $\mathrm{C}$, the endothelial cell nuclei remained intact; however, many distinctive vacuoles were apparent in cytoplasm of these cells. Large vacuoles (indicated by red arrows) had formed in endothelium so that the junction between endothelium and the basement membrane was broken. The elastic layer had also been damaged and was discontinuous and incomplete (Fig. 2E and 2F).

Various effects of different fluoride ion concentration on HUVEC proliferation

In order to determine the optimal fluoride ion concentration, we treated cultured endothelial cells with different concentrations of $\mathrm{NaF}$ (as shown in Fig. 3A). At cell medium 
Fig. 3. Effects of different fluoride ion concentrations on HUVEC proliferation and ET1 gene and ECE-1 expression in HUVECs and ET-1 levels in cell culture supernatants of different groups. Part A shows the various effects of different fluoride ion concentrations on HUVEC proliferation. Part B shows the levels of ET1 gene expression in HUVECs of different experimental groups. Part $\mathrm{C}$ shows the levels of ET-1 in HUVEC culture supernatants of different experimental groups. Parts D and E together show the expression levels of ECE-1 and GADPH and the ratios of ECE-1/GADPH in HUVECs of different groups. The ratio of ECE-1/GAPDH shown in part D was calculated based on the expression levels of each protein. ${ }^{*} \mathrm{P}$ $<0.05$ compared with the control group.

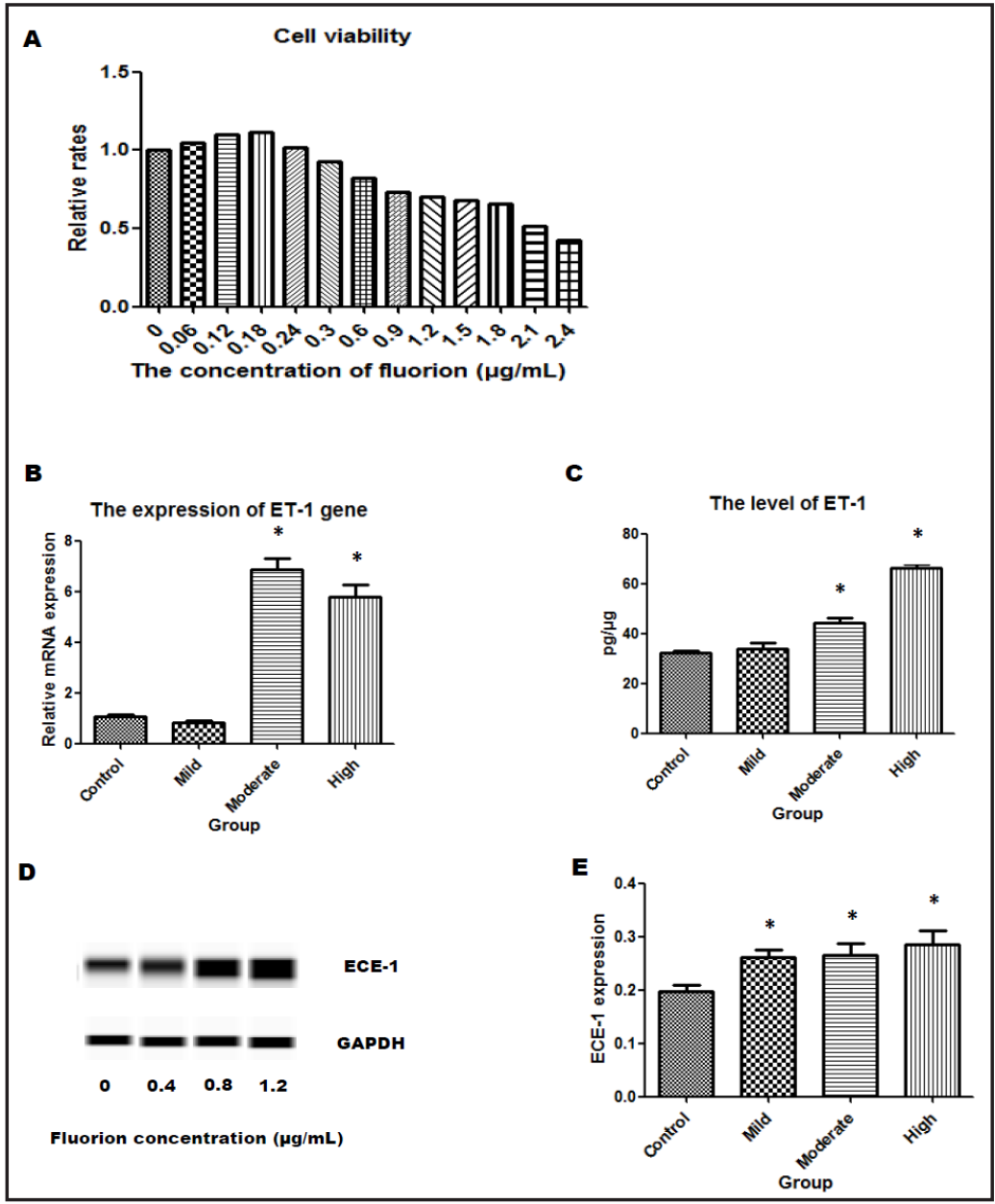

fluoride ion concentrations $\leq 0.18 \mu \mathrm{g} / \mathrm{mL}$, OD values increased gradually as fluoride ion concentration increased, indicating that these three concentrations promoted HUVECs proliferation. When the fluoride ion concentration in the medium was $\geq 0.3 \mu \mathrm{g} / \mathrm{mL}$, the $\mathrm{OD}_{450}$ value decreased as the fluoride ion concentration increased, indicating that excessive fluoride ion exposure inhibited HUVECs proliferation. Finally, three experimental dose groups, which were treated with low $(0.4 \mu \mathrm{g} / \mathrm{mL})$, moderate $(0.8 \mu \mathrm{g} / \mathrm{mL})$, and high $(1.2 \mu \mathrm{g} /$ $\mathrm{mL}$ ) concentrations of fluoride ion, were organized and compared with the control group (no fluoride ion in the medium).

ET1 gene expression levels of HUVECs increased significantly in the moderate- and highdose groups

The expression levels of ET1 gene in HUVECs of different groups (n=4) are shown in Figure 3B. ET1 gene expression levels differed significantly among all the groups ( $\mathrm{F}=88.58$, $\mathrm{P}<0.001$; Fig. 3B). ET1 gene expression levels in moderate-dose group were significantly higher than those in other groups $\left(\mathrm{P}_{\text {moderate vs control }}<0.001, \mathrm{P}_{\text {moderate vs low }}<0.001, \mathrm{P}_{\text {moderate vs high }}\right.$ $=0.043$ ), and ET1 gene expression levels in high-dose group were significantly higher than those in control and low-dose groups $(\mathrm{P}<0.001)$. However, there was no significant difference in ET1 gene expression levels between the low-dose and control groups $(\mathrm{P}=0.621)$.

ET-1 levels in cell culture supernatants of moderate- and high-dose groups were significantly higher than those of low-dose and control groups

ET-1 expression levels in cell culture supernatants of different groups $(n=4)$ are shown in Figure 3C. ET-1 levels in cell culture supernatants of three dose groups increased gradually as cell medium fluoride ion concentrations increased, and significant differences in ET-1 

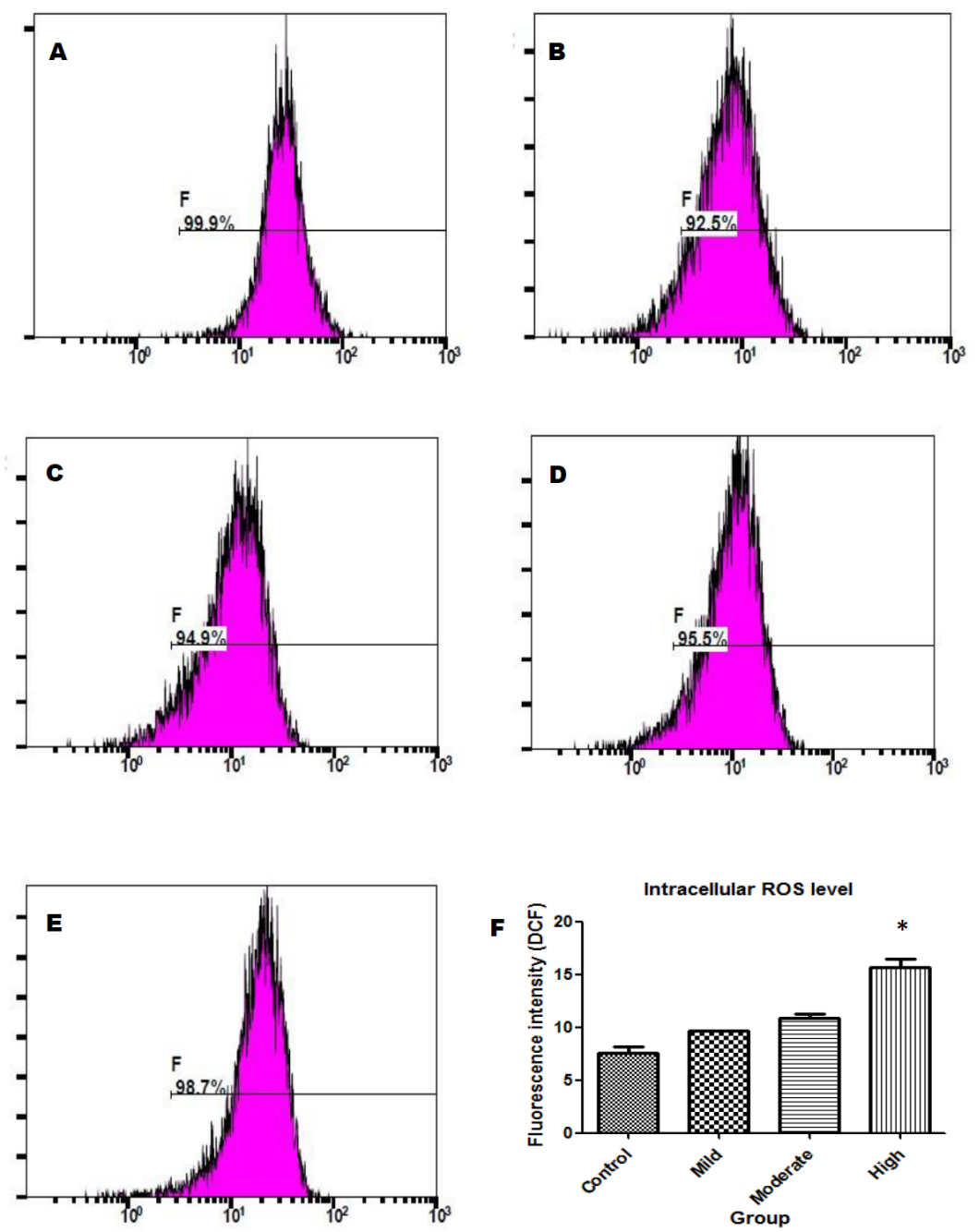

continued

Fig. 4. Intracellular ROS levels, RAS activation levels, and pERK1/2-to-ERK1/2 ratios in HUVECs of different groups and ECE-1 expression levels in HUVECs and ET-1 levels in cell culture supernatants after treatment with $1.2 \mu \mathrm{g} / \mathrm{mL}$ fluoride ion with or without U0126 pretreatment. Parts A, B, C, D, and E show the positive control, control, low-, moderate- and high-dose groups, respectively. Part F shows a comparison of the intracellular ROS levels in different groups. Part G shows the RAS activation levels in different groups. Parts $\mathrm{H}$ and I together show the expression levels of pERK1/2 and ERK1/2 and the ratios of pERK1/2 to ERK1/2 in HUVECs of different groups. The ratios of pERK1/2 to ERK1/2 were calculated from the expression levels of these proteins. ${ }^{*} \mathrm{P}<0.01$ compared with the control group. Parts J and $\mathrm{K}$ together show expression levels of ECE-1 in HUVECs of two different groups. The ratios of ECE-1/GAPDH were calculated based on the expression levels of these proteins. Part L shows the levels of ET-1 in cell supernatants of two different groups. ${ }^{*} \mathrm{P}<0.01$ compared with the $1.2 \mu \mathrm{g} / \mathrm{mL}$ group.

levels were noted among all groups $(\mathrm{F}=77.06, \mathrm{P}<0.001)$. ET- 1 levels in the high-dose group were significantly higher than those in all other groups $(\mathrm{P}<0.001)$, and ET- 1 levels in the moderate-dose group were significantly higher than those in control and low-dose groups $\left(\mathrm{P}_{\text {moderate vs control }}<0.001, \mathrm{P}_{\text {moderate vs low }}=0.001\right)$. However, there was no significant difference in ET-1 levels between low-dose and control groups $(\mathrm{P}=0.535)$.

ECE-1 expression levels of HUVECs increased significantly in three dose groups

ECE-1 expression levels in HUVECs of three dose groups ( $n=3)$ also increased gradually as fluoride ion concentrations increased, and significant differences in ECE-1 expression 
G

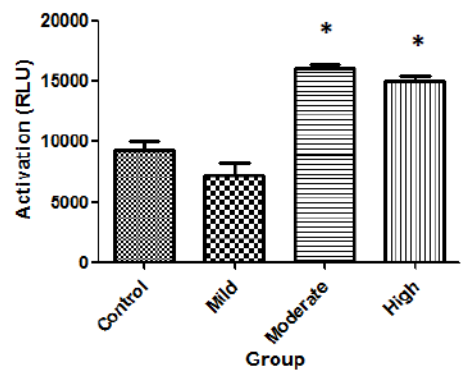

I

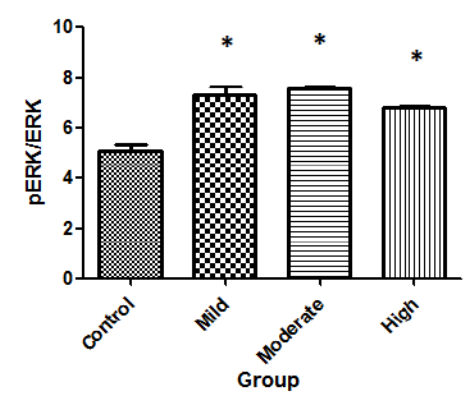

$\mathbf{K}$

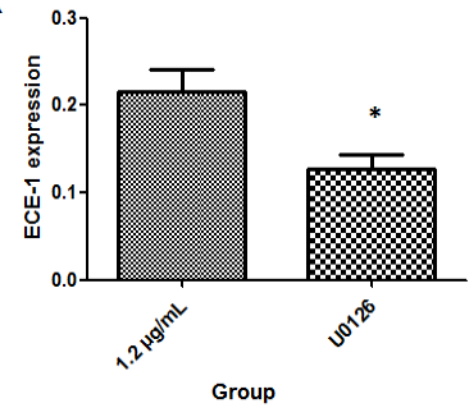

H

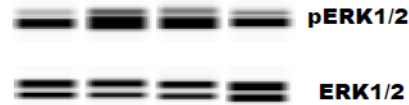

$\begin{array}{llll}0 & 0.4 & 0.8 & 1.2\end{array}$

Fluorion concentration ( $\mu \mathrm{g} / \mathbf{m L}$ )

J

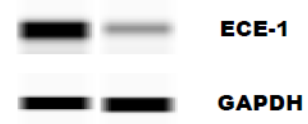

$1.2 \mu \mathrm{g} / \mathrm{mL} \quad$ U0126

Group

$\mathbf{L}$

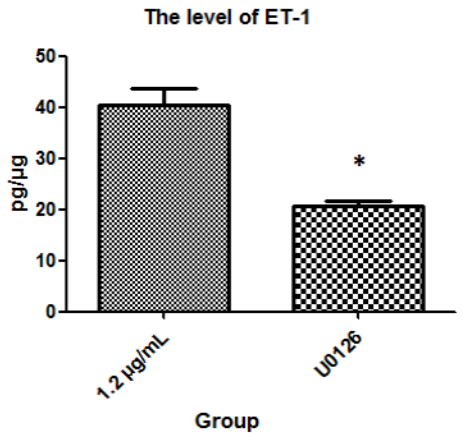

levels were observed among all groups ( $\mathrm{F}=3.99, \mathrm{P}=0.027)$. ECE-1 expression levels in low-, moderate- and high-dose groups were significantly higher than that in the control group $\left(\mathrm{P}_{\text {low vs control }}=0.031, \mathrm{P}_{\text {moderate vs control }}=0.023, \mathrm{P}_{\text {high vs control }}=0.005 ;\right.$ Fig. $3 \mathrm{D}$ and $\left.3 \mathrm{E}\right)$. However, the differences in ECE-1 levels among low-, moderate-, and high-dose groups were not significant.

Intracellular ROS levels increased significantly in the high-dose group

The levels of intracellular ROS in all experimental groups $(n=3)$ are shown in Figure 4AF. There were significant differences in ROS levels among these groups $(\mathrm{F}=40.32, \mathrm{P}<0.001)$. Intracellular ROS level in the high-dose group were significantly higher than that in the control group $(\mathrm{P}=0.007)$, but the differences in intracellular ROS levels among other three groups were not significant $\left(\mathrm{P}_{\text {low vs control }}=0.230, \mathrm{P}_{\text {moderate vs control }}=0.064\right)$.

RAS activation levels in moderate- and high-dose groups were significantly higher than those in control and low-dose groups

After $24 \mathrm{~h}$ of fluoride ion treatment, we assessed RAS activation in HUVECs of different groups $(n=3)$. The details of this assessment are shown in Figure 4G. There were significant differences in RAS activation among all groups $(\mathrm{F}=44.65, \mathrm{P}<0.001)$. RAS activation levels in moderate- and high-dose groups were significantly higher than those in control and low-dose 


\section{Cellular Physiology Cell Physiol Biochem 2016;40:861-873 \\ \begin{tabular}{l|l|l} 
and Biochemistry Published online: December 07, 2016 & $\begin{array}{l}\text { C } 2016 \text { The Author(s). Published by S. Karger AG, Basel } \\
\text { www.karger.com/cpb }\end{array}$
\end{tabular} \\ Sun et al.: Mechanisms of Fluorosis}

groups $\left(\mathrm{P}_{\text {moderate vs control }}<0.001, \mathrm{P}_{\text {high vs control }}<0.001, \mathrm{P}_{\text {moderate vs low }}<0.001, \mathrm{P}_{\text {high vs low }}<0.001\right)$. The moderate- and high-dose groups did not differ significantly with respect to RAS activation $(\mathrm{P}=0.226)$, nor did the low-dose and control groups $(\mathrm{P}=0.060)$.

The $p E R K 1 / 2$-to-ERK1/2 ratios increased significantly in all three dose groups

Significant differences in the ratio of pERK1/2/ERK1/2 were observed among all groups ( $\mathrm{F}=26.68, \mathrm{P}<0.001$; Fig. $4 \mathrm{H}$ and $4 \mathrm{I}$ ). The pERK1/2-to-ERK1/2 ratios in low-, moderate-, and high-dose groups were significantly higher than that in the control group $\left(\mathrm{P}_{\text {low vs control }}<0.001\right.$, $\mathrm{P}_{\text {moderate vs control }}<0.001, \mathrm{P}_{\text {high vs control }}=0.001$ ), but low, moderate, and high dose groups did not differ significantly from one another with respect to their pERK1/2-to-ERK1/2 ratios.

Both ECE-1 expression levels in HUVECs and ET-1 levels in cell culture supernatants clearly decreased after pretreatment with U0126.

Based on previous results, we established two new experimental groups for this portion of the study. The HUVECs in the $1.2 \mu \mathrm{g} / \mathrm{mL}$ group were treated with only $1.2 \mu \mathrm{g} / \mathrm{mL}$ fluoride ion for $24 \mathrm{~h}$, and the HUVECs in the U0126 group were pretreated with $10 \mu \mathrm{M}$ U0126 for $1 \mathrm{~h}$ before the addition of $1.2 \mu \mathrm{g} / \mathrm{mL}$ fluoride ion for $24 \mathrm{~h}$. ECE- 1 expression levels in the U0126 group were significantly lower than those in the $1.2 \mu \mathrm{g} / \mathrm{mL}$ group $(\mathrm{t}=2.82, \mathrm{P}=0.037$; Fig. 4J and 4K). Similarly, ET-1 levels in cell culture supernatants of the U0126 group were significantly lower than that in cell culture supernatants of the $1.2 \mu \mathrm{g} / \mathrm{mL}$ group $(\mathrm{t}=5.88$, $\mathrm{P}=0.007$; Fig. 4L).

\section{Discussion}

In this study, we found that excessive fluoride exposure leads to oxidative stress and increased intracellular ROS levels, which might be involved in ET-1 over-expression. And all the results suggested that the fluoride induce ET-1 over-expression-at least in part-via the ROS-RAS-MEK1/2-ERK1/2 signaling pathway in endothelial cells. In our animal model, we observed characteristic vacuoles in cytoplasm of endothelial cell of rabbits treated with high concentrations of fluoride. This damage may be associated with the increase of ET- 1 levels along with oxidative stress. Gross examination and transmission electron microscopy both demonstrated that the thoracic aortas of fluoride-exposed rabbits were slightly hardened compared with those of control rabbits.

The fluorine in the human body (approximately $2.6 \mathrm{~g}$ ) is mainly present in bones and teeth, although small amounts are present in soft tissues, such as the heart, blood vessels, kidneys, and liver. Approximately 75\%-90\% of dietary fluoride is absorbed quickly by the gastrointestinal tract and enters the bloodstream, which distributes fluoride throughout body in the form of the fluoride ion. The kidney is the main fluoride ion excretion organ, and approximately $50 \%-80 \%$ of the fluoride ions in body are excreted via urine each day. Measures of internal fluorine levels, including serum fluoride ion levels, urine fluoride ion levels and bone fluoride ion content, were the main indicators used to assess whether an animal model of fluorosis was established successfully. In this study, fluoride ion levels in serum and fluoride ion content in bone were selected as indicators of the fluorine load in the body. Together, these parameters demonstrated that the animal model of fluorosis was established successfully when NaF was administered via drinking water. The body weights of rabbits in all groups did not differ significantly, and the growth curves for body weight were similar among the three rabbit groups, suggesting that these two fluoride doses had little impact on rabbit growth and development.

In our animal experiment, transmission electron microscopy showed that the elastic layers of rabbit aortas in groups B and C had been damaged and were discontinuous and incomplete. Gross examination showed that thoracic aorta elasticity had deteriorated in rabbits of two fluorinated groups, as the aortas in these groups exhibited slight hardening compared with those in the control group. Several studies have shown that with increases in fluoride concentrations in drinking water, vascular compliance decreases, and vessel 


\section{Cellular Physiology Cell Physiol Biochem 2016;40:861-873

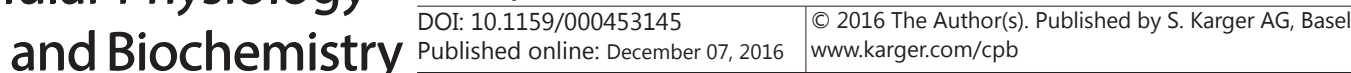 \\ Sun et al.: Mechanisms of Fluorosis}

stiffness increases $[4,21,22]$. This stiffness is closely related to oxidative stress [23, 24]. In our previous study, we found that excess intake of fluoride via drinking water significantly increased lipid peroxidation and malondialdehyde levels and caused oxidative stress products to accumulate [25], indicating that oxidative stress caused by excess fluoride intake may play an important role in vascular stiffness observed in experimental animals.

To our knowledge, this study is unique in that we detected characteristic vacuoles in cytoplasm of endothelial cell of rabbits exposed to high levels of fluoride. Large vacuoles raised the endothelium so that the junction between endothelium and the basement membrane was broken. These vacuoles also passively disrupted the tight junctions between endothelial cells, causing the channels between endothelial cells to open, thereby increasing the permeability of the endothelial cell layer. These results, as well as the results of previous epidemiological studies conducted by our team [6], suggested that this vacuolation might play a role in atherosclerosis caused by high fluoride exposure.

Endothelial injury can - to some extent-be reflected by increases in ET-1 levels. In our animal experiment, in parallel with damage to the endothelium, the levels of ET-1 in plasma of rabbits in two fluorinated groups increased. This increase may also have been related to an increase in oxidative stress. Generally, ET-1 synthesis is influenced by many factors, such as oxidative stress [16]. It is well-documented that oxidative stress plays an important role in the pathogenesis of endemic fluorosis [26-28]. Therefore, based on the data described above [25], we inferred that oxidative stress may be a modulator of fluoride-induced ET-1 over-expression.

This inference was verified in our subsequent cell experiment, in which fluorideinduced ET-1 expression and ROS generation were inseparable. In one hand, ROS enhances ET1 gene transcription. Previous studies have reported that ROS play an important role in ET1 gene expression in the endothelium. ROS activate nuclear transcription factor activator protein 1 through the phosphorylation of ERK1/2. Transcription factor activator protein 1 then combines with the functional components of promoter of the ET1 gene, ultimately promoting the transcription of the ET1 gene [29, 30]. In present study, ET-1 mRNA expression increased as intracellular ROS levels increased, demonstrating that ROS are very important in fluoride-induced ET-1 mRNA over-expression. In the other hand, ROS also promote ET-1 synthesis and secretion. The levels of ET- 1 in the cell culture supernatants and the expression levels of ECE-1 in the HUVECs of the three dose groups increased compared with that in the control group. These trends paralleled the trends in intracellular ROS levels in three dose groups. This consistency among ET-1 levels, ECE-1 expression levels, and intracellular ROS levels suggests that ROS are a crucial factor in ET-1 synthesis and secretion. In summary, the combined results of our animal and cell experiments support the notion that oxidative stress caused by excessive fluoride exposure is involved in ET-1 synthesis and secretion.

More importantly, our results suggest that the RAS-MEK1/2-ERK1/2 pathway is required for fluoride-induced ET-1 over-expression. To explore whether the ERK1/2 pathway participates in fluoride-induced ET-1 over-expression in HUVECs, we examined pERK1/2 and ERK1/2 expression. Our results show that the ratios of pERK1/2 to ERK1/2 were significantly higher in low-, moderate-, and high-dose groups than that in the control group. The trends in pERK1/2/ERK1/2 expression in the different groups were similar to the changes in the levels of ET-1 in cell culture supernatants and the expression levels of ECE-1 in HUVECs. These findings suggest that ERK1/2 pathway activation is a necessary step in fluoride-induced ET-1 over-expression. Based on the results in vitro study, we also inferred that ROS were involved in fluoride-induced ERK1/2 pathway activation because the changes in ROS levels among the different groups also paralleled the changes in the pERK1/2-to-ERK1/2 ratio. This inference is consistent with the results of a previous study $[29,31]$.

ERKs are serine/threonine protein kinases activated by the upstream RAS-RAF-MAPK/ ERK (MEK) cascade [32]. In order to determine whether this signaling pathway is involved in fluoride-induced ET-1 over-expression, we also assessed RAS activation. Our results show that RAS activation was significantly elevated in moderate- and high-dose groups compared 


\section{Cellular Physiology Cell Physiol Biochem 2016;40:861-873 \begin{tabular}{l|l|l}
\hline and BOI 10.1159/000453145 & $\begin{array}{l}\text { C } 2016 \text { The Author(s). Published by S. Karger AG, Basel } \\
\text { www.karger.com/cpb }\end{array}$
\end{tabular} \\ Sun et al.: Mechanisms of Fluorosis}

with that in the control group. Pretreatment with U0126 clearly abolished ET- 1 and ECE-1 over-expression in fluoride-treated HUVECs, implying that MEK1/2 activation is required in this process. All these results suggested that the RAS-MEK1/2-ERK1/2 signaling pathway plays a key role in fluoride-induced ET-1 over-expression in HUVECs.

\section{Abbreviations}

BCA, (bicinchoninic acid); ECE-1, (endothelin-converting enzyme 1); ELISA, (enzymelinked immunosorbent assay); ET-1 (endothelin1); ERK1/2 (extracellular signal-regulating kinase 1/2); HUVECs (human umbilical vein endothelial cells); MAPK (mitogen-activated protein kinase); MEK (MAPK/ERK); OD (optical density); PBS (phosphate-buffered saline); pERK1/2 (phosphorylated ERK1/2); qPCR (quantitative PCR); ROS (reactive oxygen species).

\section{Acknowledgments}

This study was financially supported by the projects of the China Postdoctoral Science Foundation (2015M581486) and the Postdoctoral Science Foundation of Heilongjiang Province (LBH-Z14139).

\section{Disclosure Statement}

The authors declare no conflicts of interest.

\section{References}

1 Wu, Gu G, Zhang, Wang, Wu C, Gu X, Ge Y, Zhang J, Wang J: Effects of high fluoride and arsenic on brain biochemical indexes and learning-memory in rats. Fluoride 2006;39:274-279.

2 Chandrajith R, Dissanayake CB, Ariyarathna T, Herath HM, Padmasiri JP: Dose-dependent na and ca in fluoride-rich drinking water--another major cause of chronic renal failure in tropical arid regions. Sci Total Environ 2011;409:671-675.

3 Chattopadhyay A, Podder S, Agarwal S, Bhattacharya S: Fluoride-induced histopathology and synthesis of stress protein in liver and kidney of mice. Arch Toxicol 2011;85:327-335.

4 Amini H, Shahri SMT, Amini M, Mehrian MR, Mokhayeri Y, Yunesian M: Drinking water fluoride and blood pressure? An environmental study. Biol Trace Elem Res 2011;144:157-163.

5 Sun L, Gao Y, Liu H, Zhang W, Ding Y, Li B, Li M, Sun D: An assessment of the relationship between excess fluoride intake from drinking water and essential hypertension in adults residing in fluoride endemic areas. Sci Total Environ 2013;443:864-869.

6 Liu H, Gao Y, Sun L, Li M, Li B, Sun D: Assessment of relationship on excess fluoride intake from drinking water and carotid atherosclerosis development in adults in fluoride endemic areas, china. Int J Hyg Environ Health 2014;217:413-420.

7 Han H, Du W, Zhou B, Zhang W, Xu G, Niu R, Sun Z: Effects of chronic fluoride exposure on object recognition memory and mrna expression of snare complex in hippocampus of male mice. Biol Trace Elem Res 2014;158:58-64.

8 Ding Y, YanhuiGao, Sun H, Han H, Wang W, Ji X, Liu X, Sun D: The relationships between low levels of urine fluoride on children's intelligence, dental fluorosis in endemic fluorosis areas in hulunbuir, inner mongolia, china. J Hazard Mate 2011;186:1942-1946.

9 Kawanabe Y, Nauli SM: Endothelin. Cell Mol Life Sci 2011;68:195-203.

10 Lin YJ, Juan CC, Kwok CF, Hsu YP, Shih KC, Chen CC, Ho LT: Endothelin-1 exacerbates development of hypertension and atherosclerosis in modest insulin resistant syndrome. Biochem Biophys Res Commun 2015;460:497-503. 


\section{Cellular Physiology Cell Physiol Biochem 2016;40:861-873

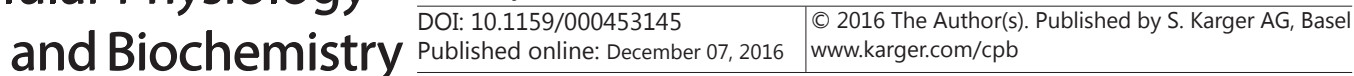 \\ Sun et al.: Mechanisms of Fluorosis}

11 Vita JA: Endothelial function. Circulation 2011;124:906-912.

12 Khimji AK, Rockey DC: Endothelin--biology and disease. Cell Signal 2010;22:1615-1625.

13 Tsuprykov O, Chaykovska L, Kretschmer A, Stasch JP, Pfab T, Krauserelle K, Reichetzeder C, Kalk P, Adamski J, Hocher B: Endothelin-1 overexpression improves renal function in enos knockout mice. Cell Physiol Biochem 2015;37:1474-1490.

14 Wang RX, He RL, Jiao HX, Dai M, Mu YP, Hu Y, Wu ZJ, Sham JS, Lin MJ: Ginsenoside rb1 attenuates agonistinduced contractile response via inhibition of store-operated calcium entry in pulmonary arteries of normal and pulmonary hypertensive rats. Cell Physiol Biochem 2015;35:1467-1481.

15 Yanagisawa M, Kurihara H, Kimura S, Tomobe Y, Kobayashi M, Mitsui Y, Yazaki Y, Goto K, Masaki T: A novel potent vasoconstrictor peptide produced by vascular endothelial cells. Nature 1988;332:411-415.

16 Emoto N, Yanagisawa M: Endothelin-converting enzyme-2 is a membrane-bound, phosphoramidonsensitive metalloprotease with acidic ph optimum. J Biol Chem 1995;270:15262-15268.

17 Yanagisawa H, Hammer RE, Richardson JA, Emoto N, Williams SC, Si T, Clouthier DE, Yanagisawa M: Disruption of ece- 1 and ece-2 reveals a role for endothelin-converting enzyme- 2 in murine cardiac development. J Clin Invest 2000;105:1373-1382.

18 Kedzierski RM, Yanagisawa M: Endothelin system: The double-edged sword in health and disease. Annu Rev Pharmacol Toxicol 2003;41:851-876.

19 Eringa EC, Stehouwer CD, Gp VNA, Ouwehand L, Westerhof N, Sipkema P: Vasoconstrictor effects of insulin in skeletal muscle arterioles are mediated by erk1/2 activation in endothelium. Am J Physiol Heart Circ Physiol 2004;287:H2043-H2048.

20 Kwon S, Lee WJ, Fang LH, Kim B, Ahn HY: Mitogen-activated protein kinases partially regulate endothelin1-induced contractions through a myosin light chain phosphorylation-independent pathway. J Vet Med Sci 2003;65:225-230.

21 Varol E, Akcay S, Ersoy IH, Ozaydin M, Koroglu BK, Varol S: Aortic elasticity is impaired in patients with endemic fluorosis. Biol Trace Elem Res 2010;133:121-127.

22 Varol E, Varol S: Effect of fluoride toxicity on cardiovascular systems: Role of oxidative stress. Arch Toxicol 2012;86:1627-1627.

23 Delles C, Zimmerli LU, Mcgrane DJ, Koh-Tan CH, Pathi VL, Mckay AJ, Steedman T, Dargie HJ, Hamilton CA, Dominiczak AF: Vascular stiffness is related to superoxide generation in the vessel wall. J Hypertens 2008;26:946-955.

24 Noma K, Goto C, Nishioka K, Jitsuiki D, Umemura T, Ueda K, Kimura M, Nakagawa K, Oshima T, Chayama K: Roles of rho-associated kinase and oxidative stress in the pathogenesis of aortic stiffness. J Am Coll Cardiol 2011;49:698-705.

25 Sun L, Gao Y, Zhang W, Liu H, Sun D: Effect of high fluoride and high fat on serum lipid levels and oxidative stress in rabbits. Environ Toxicol Pharmacol 2014;38:1000-1006.

26 Xi S, Liu Z, Yan L, Wang F, Sun G: A role of fluoride on free radical generation and oxidative stress in bv-2 microglia cells. Mediators Inflamm 2012;2012:102954.

27 Varol E, Icli A, Aksoy F, Bas HA, Sutcu R, Ersoy IH, Varol S, Ozaydin M: Evaluation of total oxidative status and total antioxidant capacity in patients with endemic fluorosis. Toxicol Ind Health 2013;29:175-180.

28 Ailani V, Gupta RC, Gupta SK, Gupta K: Oxidative stress in cases of chronic fluoride intoxication. Indian J Clin Biochem 2009;24:426-429.

29 Hsu YH, Chen JJ, Chang NC, Chen CH, Liu JC, Chen TH, Jeng CJ, Chao HH, Cheng TH: Role of reactive oxygen species-sensitive extracellular signal-regulated kinase pathway in angiotensin ii-induced endothelin-1 gene expression in vascular endothelial cells. J Vasc Res 2004;41:64-74.

30 Achmad TH, Winterscheidt A, Lindemann C, Rao GS: Oxidized low density lipoprotein acts on endothelial cells in culture to enhance endothelin secretion and monocyte migration. Methods Find Exp Clin Pharmacol 1997;19:153-159.

31 Cheng TH, Shih NL, Chen SY, Loh SH, Cheng PY, Tsai CS, Liu SH, Wang DL, Chen JJ: Reactive oxygen species mediate cyclic strain-induced endothelin-1 gene expression via ras/raf/extracellular signal-regulated kinase pathway in endothelial cells. J Mol Cell Cardiol 2001;33:1805-1814.

32 Kim EK, Choi EJ: Compromised mapk signaling in human diseases: An update. Arch Toxicol 2015;89:867882. 